\title{
Ethics in University: Cognitive Moral Development and Gender
}

\author{
Dovi SEPTIARI ${ }^{1}$, Nayang HELMAYUNITA ${ }^{2}$, Vanica SERLY ${ }^{3}$, Vita Fitria SARI ${ }^{4}$ \\ Received: September 01, 2020 Revised: October 26, 2020 Accepted: November 05, 2020
}

\begin{abstract}
This study examines the accounting students' level of moral development at the university. In this study, we focused on the effects of ethics subject and gender on moral development. Therefore, we compare the moral development of male and female students. We evaluated 216 students in Cognitive Moral Development (CMD) from 17 universities in Indonesia. We measured CMD with the Defining Issues Test (DIT) model developed by Rest in 1986. The findings show that there is no difference in DIT scores between students who have taken the ethics subject and who have not taken. We also confirm female students have a higher DIT score than male students. Our study results show that gender plays an important role in the ethics issue. Our study strengthens the previous research about the effect of ethics study and ethics courses on CMD. This study has an implication for ethics education in university wherein the curriculum or the system should be prepared carefully. Although the results of this study did not show that ethics subject has a strong impact on students' CMD, we still believe that the ethics course plays a significant role in the accountants' morals. For that reason, we argue that morals need time to be developed, and cannot be taught in a short-term course. Future research is needed to explore more about this issue.
\end{abstract}

Keywords: Cognitive Moral Development, Ethics, Accounting Students, Gender

JEL Classification Code: C91, M48, M53

\section{Introduction}

The auditor accepts responsibility for examining financial statements prepared by the company and verifying compliance with reporting standards (Staubus, 2005). However, many conflicts of interest emerging between the auditor and management may degrade the auditors' independence (Goldman \& Barlev, 1974). These conflicts sometimes force auditors to take unethical decisions. Arfaoui et al. (2016), Gaa \& Thorne (2004), and Septiari

${ }^{1}$ First Author. Lecturer, Accounting Department, Universitas Negeri Padang, Indonesia

${ }^{2}$ Corresponding Author. Lecturer, Accounting Department, Universitas Negeri Padang, Indonesia [Postal Address: Jl. Prof. Dr. Hamka, Air Tawar, Padang, 25171, Indonesia] Tel: +62 8136334 8995,

Email: nayang.helma@fe.unp.ac.id ; nayang.helma@gmail.com

${ }^{3}$ Lecturer, Accounting Department, Universitas Negeri Padang, Indonesia

${ }^{4}$ Lecturer, Accounting Department, Universitas Negeri Padang, Indonesia

(C) Copyright: The Author(s)

This is an Open Access article distributed under the terms of the Creative Commons Attribution Non-Commercial License (https://creativecommons.org/licenses/by-nc/4.0/) which permits unrestricted non-commercial use, distribution, and reproduction in any medium, provided the original work is properly cited.
\& Maruli (2017) suggest that the rise of accounting cases like fraud and earning management (the use of accounting techniques to produce financial statements that present an overly positive view of a company's business activities and financial position) insist on the necessity of ethical behavior.

Ponemon (1990) collected relevant data from several previous studies that stated professional accountants fail to bring out moral reasoning capacity compared to people with the same educational and socioeconomic backgrounds. This can be a serious problem because accountants have substantial responsibility in their professional work. The results of these previous studies led to the conclusion that ethics plays a prominent role.

Universities must prepare accountants in their work field. Furthermore, they have a responsibility to prepare students not only to gain accounting competence but also to be aware of ethics. Alimbudiono (2020) reported that the professional accounting field is dominated by people who are over 50 years of age. If universities neglect this area, then the availability of junior accountants in the workforce will decrease. Furthermore, Alimbudiono (2020) stated that knowledge plays an important role to resolve this problem. In our opinion, accounting competence and ethics are extremely important for accounting students. 
Gaa \& Thorne (2004) stressed that ethics must be imbibed in auditors when studying at the university. Ethics skills will encourage the auditor to have high integrity. Also, ethical education for students is an important factor that evokes confidence in the accounting profession (Ponemon, 1990). Previous studies by Langenderfer \& Rockness (1989), Lockwood (1978), O’Leary (2012), Shaub (1994), and Thorne (2001) confirmed that ethics education has a goal to support students'moral improvement. Thus, accounting academicians have a significant duty to impart ethics knowledge with a compatible curriculum for students (Staubus, 2005). According to Aryanti \& Adhariani (2020), both professional and students agreed that ethics is an important skill to be developed and universities must embed this subject into the curriculum. Arfaoui et al. (2016) also confirmed that ethical education is effective in increasing students' ethical behavior

The purpose of our research is twofold. First, we analyze the accounting ethics through Cognitive Moral Development (CMD) on students at university. We do this research to re-examine Armstrong (1987) statement that education in universities or higher level might not have taken care of the moral development of accounting students. This is immensely worrying because accounting firms need to recruit accountants with higher levels of cognitive moral development, often referred to as moral reasoning (Abdolmohammadi, Read, \& Scarbrough, 2003). The failure of universities to promote students' cognitive moral development will increase critics of the accounting profession. Therefore, it is important to undertake more research on this matter. In our study, we compare the ethical capacity between fresher students and final year students. We expect that this study contributes to the understanding of the ethical improvement of accounting students at the university.

Secondly, we compare the moral development of male students and female students. In business research, studies about gender have inconsistent results. Ho, Dao, \& Phan (2020) suggest that gender diversity plays a significant role in a loan approval. However, in the 'corporate sustainability performance' issue, gender diversity has no impact (Fakir \& Jusoh, 2020). Especially in the business ethics context, some of the previous studies also showed inconsistent results (Ariail, Abdolmohammadi, \& Smith, 2012). An earlier study by Murphy \& Rest (1980) revealed that gender does not contribute to moral reasoning capacity. Thoma (1986) found that men have less moral reasoning abilities compared to women. In the accounting context, there have been some contradictory studies that state women have less moral reasoning abilities while others argue the opposite (Ariail et al., 2012). This issue is challenging for the researcher and the results can assist the researcher to do more studies in this area as well as assist the academician to compose the best ethics curriculum for universities. Ariail et al. (2012) suggest the further research must use a broad sample to fix the inconsistent outcome and use the sample across the university.

This study employs 216 accounting students from 17 universities in Indonesia. We measured the moral development using the Defining Issues Test (DIT) model developed by Rest (1986). The results of our study confirm that there is no difference in the DIT score between junior and senior students. Then, we found intense support that females have a higher DIT score than males. This study states that ethics must be the priority in universities. Our findings showed that the study of ethics at universities may not have been good. Setting up the curriculum for ethics is required, as most of the previous studies confirm that ethics education is effective in constructing students' morality.

\section{Literature Review}

\subsection{Kohlberg's Cognitive Moral Development (CMD) Theory}

Ethical decision making is a rational process in which individuals use reason in dealing with moral dilemmas by applying moral principles or other criteria which they believe (Kohlberg, 1971, 1973). In short, the CMD theory explains the maturity of an individual's moral development decision. Kohlberg states that social experiences stimulate our mental processes in moral development. As such, moral behavior stems from moral considerations and cognitive ethics (Kohlberg, 1976).

Kohlberg investigated the individual's responses to the hypothetical moral dilemmas established by the moral stage achievement. Kohlberg has focused on moral development and has proposed a stage theory of moral thinking. A higher stage accomplishment means a higher moral. Kohlberg proposed six stages of moral judgment, grouped into three levels: pre-conventional, conventional, and post-conventional. Kohlberg(1971, 1976), all individuals progress starts from the beginning level at "pre-conventional morality," up to "conventional morality" and then may achieve the highest stage at "post-conventional morality". Kohlberg's model contains six stages of moral reasoning within three levels of moral development that centered on cognitive reasoning (or rationality) (Kohlberg, 1971). Movement from one level to the next level in CMD entails the re-organization of a form of thought into a new form (DeTienne et al., 2019). Not all individuals can achieve the six stages because it is rare to find people who reach stage five or six, emphasizing that Kohlberg's idea of the stages of moral development was not synonymous with maturation (Kohlberg, 1971). According to this argument, DeTienne et al. (2019) stated that new thinking strategies do not originate from direct instruction, but from active thinking about moral ethical issues. 
Kohlberg (1971) explains that in the stages one and two (pre-conventional), the right decision chosen by the individuals should be based on the purpose to avoid punishment or to serve one's interest. Pre-conventional people are not aware of the differences between individuals (Kohlberg, 1971). In this phase, individuals will view moral actions as physical and are not aware of the psychological interests of others. In stages three and four (conventional), individuals are aware of shared feelings, agreements, and expectations that prioritize individual interests. Thus, they need to be a good person because of colleagues, management, and the profession as a whole (Kohlberg, 1971). In the last stages, five and six (post-conventional), individuals follow self-selected ethical principles in terms of certain legal or social agreements received by the public (Kohlberg, 1971). However, if a law or an ethical rule violates these principles, someone will act based on the principle rather than obey the rules (Kohlberg, 1971).

According to McPhail \& Walters (2009), the CMD model can be applied to accounting students and practitioners at various stages in their careers. For instance, the applications of the model in accounting are investigated by Ponemon (1990). According to Ponemon (1990), CMD has an important role in unreported problems. His research confirms that the accountants' moral development improved until they become a manager or a partner, and after a certain point it will decrease.

Our study examines the accounting students' level of moral development. It will investigate how universities set up the curriculum which facilitated moral development in students. This research will identify which morals or ethics should be developed by educational institutions, especially for accounting study.

\subsection{Accounting Ethics Education}

Ethics education will build the credibility of the accounting profession (Ponemon, 1990). Its purpose is to drive students' moral development at universities (Lockwood, 1978; O’Leary, 2012; Shaub, 1994; Thorne, 2001). Good ethics will generate an ethical accountant. It will reduce the unethical behavior of accountants. The need for ethics rises rapidly because there are so many unethical cases that have happened lately. Abdolmohammadi et al. (2003)suggested that the ethical training of accountants has become more crucial and significant than before, particularly at the university.

Ethical education in the field of auditing follows the basic provision that moral principles can be improved through the learning process (Lockwood, 1978; Shaub, 1994; Thorne, 2001). In the pre-qualification period, that is, the university, the more effective ethical input can increase ethical values to a higher level of ethical reasoning (Ponemon, 1990). Cognitive psychology has two viewpoints to raise accounting students' ethics awareness, namely, cognitive development theory and assimilation learning theory (Ausubel, 1962).

Kohlberg's theoretical basis for moral development shows that a person's morality develops and changes over time. Such that later, the accounting profession can improve the level of moral development of the accountant (Dellaportas, Cooper, \& Leung, 2006). However, assimilation learning theory states that each student has an initial cognitive structure for each educational topic. This cognitive structure is arranged hierarchically in terms of conceptual traces, in which specific sub-concept traces and data information will be included (Ausubel, 1962). This data is estimated by individuals such that ethical behavior will develop into the next stage of the hierarchy in the long term or what is called ethical maturity

This study will examine students' moral development at the university. We try to see that ethics education at universities will promote improved ethical behavior in students. The methodological approach is based on the cognitive development theory. It contributes to the understanding of the various levels of the theory related to the ethical reasons of auditors who face ethical dilemmas. We predict that the students who have taken the ethics subject will have a higher level of CMD than the students who have not taken yet. These students have experience and knowledge about ethics education than their counterparts. Our first hypotheses state that:

$\boldsymbol{H}_{1}:$ Students who have taken ethics courses will have a higher DIT score than students who have not taken yet

\subsection{Gender and Moral Development}

The socialization theory states that differences in values, interests, and traits brought by men and women will cause differences in ethical perceptions (Dawson, 1992). Dawson (1992)suggests that feminine and masculine tendencies have developed since childhood. Moreover, the differences in moral values and ethical views can be identified through their daily life.

Another theory that explains gender issues in ethics is the social role theory. This theory explains that males and females will behave depending on the stereotypes inherent in the social roles they are occupying (Doherty \& Eagly, 1989). Females can be seen as more communal, concern for others, and more expressive with emotions. While males can be seen as more independent and assertive (Eagly \& Wood, 1991).

Previous studies attempt to verify the role of gender in moral development. An earlier study by Murphy \& Rest (1980) reported no difference in moral reasoning between males and females in 15 different studies. While Thoma (1986) concluded that females have higher moral ability than males through a meta-analysis of 56 studies. Arfaoui et al. (2016) confirmed similar results as Thoma (1986) that females are more sensitive to have ethical dilemmas than males. 
In the accounting context, Ariail et al. (2012) suggested that women have higher moral reasoning abilities than men. Neidermeyer, Tuten, \& Neidermeyer (2003) show that female auditors were found to be less inclined to the practice of low balling (that is, fraud and earnings management). Smith \& Rogers (2000) found that male accountants are more likely to respond ethically to suspicious client activities such as inventory manipulation. While Owhoso (2002) found no differences between males and females in the fraud risk assessment of auditors. Rogers \& Smith (2001) confirmed similar results in their study in the responses to ethical vignettes done by senior undergraduate and graduate accounting students.

Research on gender theory and gender differences shows that men and women often take different perspectives on accounting and business processes, approaches that are unique and equally valuable (Ariail et al., 2012). Ariail et al. (2012) noted that mixed results on gender effect in previous moral development studies are generally based on small samples of accounting students and auditors. Therefore, in our study, we use a larger sample across the university.

We posit in our second hypothesis that:

$\boldsymbol{H}_{2}:$ Female students have a higher DIT score than male students.

\section{Methodology}

Data was collected through an online website. 258 undergraduate students from 17 universities in Indonesia participated in this study. However, 42 students did not pass the validity that is required by Rest (1986). We gave some incentives to increase students' motivation to complete the task in our survey. They were told that they could get a voucher as appreciation if they complete the DIT.

We used DIT to measure CMD. We made a few adjustments to make the questionnaire easier for participants to understand. DIT is a self-administered questionnaire that raises the level of moral reasoning of the student. This test consists of six hypothetical conflicts and provides various problems and related responses. In our study, we just use a short form that contains four hypothetical conflicts. Students (participants) were asked to choose and rank the issues that in their opinion had the most significant influence on the resolution of each conflict presented. In DIT, points are given to each participant's response using a 4-point scale for the most important to 1 point for the least important. Points corresponding to the highest moral reasoning mode are used to construct a single measure known as P score (principled), calculated for each participant. The $\mathrm{P}$ score measures the percentage of responses in stages 5 and 6 made by an individual for all cases. The results of the $P$ score are expressed as a continuum from 0.00 to 1.00 . Besides, according to Rest (1986), a higher P score implies a lower percentage from stages 1 to 4 . The DIT P score is an objective measure for which very high statistical reliability and validity have been assessed (Rest, 1986).

\section{Results}

Table 1 shows the number of the participants $(\mathrm{N})$, the mean of P-Score, and the standard of deviation. The table shows that 56 participants are male and 160 participants are female. 61 participants study in semester 1-2, 26 participants study in semester 3-4, 44 participants study in semester 5-6 and 85 participants study in semester 7 or more.

Table 1: Descriptive Statistics

\begin{tabular}{|c|c|c|c|}
\hline Item & $\mathbf{N}$ & Mean & Std. Deviation \\
\hline \multicolumn{4}{|l|}{ Gender } \\
\hline Male & 56 & 25,893 & 12,008 \\
\hline Female & 160 & 31,094 & 15,052 \\
\hline Total & 216 & & \\
\hline \multicolumn{4}{|l|}{ Students year } \\
\hline Semester 1-2 & 61 & 26,639 & 14,782 \\
\hline Semester 3-4 & 26 & 37,788 & 14,583 \\
\hline Semester 5-6 & 44 & 33,352 & 14,844 \\
\hline Semester $>7$ & 85 & 32,588 & 15,471 \\
\hline Total & 216 & & \\
\hline \multicolumn{4}{|l|}{ Students Category } \\
\hline Pass the ethics subject & 85 & 32,588 & 15,471 \\
\hline Didn't pass the ethics subject & 131 & 31,106 & 15,318 \\
\hline Total & 216 & & \\
\hline
\end{tabular}


Table 2: ANOVA Results

\begin{tabular}{|l|c|c|c|}
\hline Source & Mean Square & F & Sig. \\
\hline Intercept & 147708,160 & 641,356 &, 000 \\
\hline Students Category & 56,579 &, 246 &, 621 \\
\hline Gender & 1782,667 & 7,740 &, 006 \\
\hline Students Category*Gender & 54,122 &, 235 &, 628 \\
\hline Error & 230,306 & & \\
\hline note: sig. at $\alpha=5 \%$ & & & \\
\hline
\end{tabular}

The first objective of our study is to examine the DIT score difference between the students who passed the ethics subject and who did not. 85 participants passed the ethics subject and 131 participants did not. According to table 1, the mean difference between these two groups is 1,48 (M-pass $=32,59$, S. D $=15,47$ and M-did not pass $=31.11$, S. D = 15,32 ) and the $p$-score is 0,621 , higher than 0,05 (Table 2). Therefore, the hypotheses one is not supported. This means that no difference was found between participants who passed the ethics subject and the participants who did not pass the ethics subject.

The second objective of our study is to examine the differences between males and females. The mean of male is 25,89 ( $\mathrm{S} . \mathrm{D}=12,01)$ and female is $31,09(\mathrm{~S} . \mathrm{D}=15,05)$. The mean difference is 5,2 significant at $p=0,06(\alpha=5 \%)$. Therefore, our second hypothesis supported that gender plays a significant role in moral development.

\section{Discussion}

First, we examine the students' moral development. To get our objective, we compare the moral development of students who have taken the ethics subject and who have not taken yet. These results confirm the previous results by (Arfaoui et al., 2016; Sorensen et al., 2017) that ethics education and ethics courses have no impact on cognitive moral development. These results have significant implications for universities that ethics courses may not work well. Arfaoui et al. (2016) suggested that ethics must be developed in a long term. This will not work in short periods with short-term courses. In our sample, the ethics subject just has two credits, and students completed this subject by one semester. However, this is not sufficient and needs to be explored more.

The university system's support is also important for this issue. Aryanti \& Adhariani (2020) found that students feel that ethics skills must be developed more at the university. However, even if students think about the importance of ethics education at the university, it has no impact on moral development if the faculty member does not support the ethics program. Adkins \& Radtke (2004) confirm this statement that students consider both business ethics and the goals of accounting ethics education to be more important than faculty members. It means that all of the university systems must support the ethics program to produce future accountant with good morals. Universities may encourage lecturers to help students to improve their knowledge of ethics within the learning process. However, it must not be taught only as one subject in one semester. Ethics must be delivered in every learning process through ethical education to enhance ethical values which will later influence students' moral development and continue in their behavior in the future career.

Integrating material on ethics contained in all courses will help students in increasing their moral maturity. Learning that is carried out continuously will have a greater effect when compared to only providing specific ethical learning that must be taken by students in one semester. More knowledge about ethics will encourage someone to live a better and moral life. Therefore, it can be concluded that the better one's ethical education, the better one's moral development (Kohlberg, 1976).

The second objective, we examine the differences in moral development between males and females. The results confirm the previous research by Ariail et al. (2012) that gender has an important role in moral development processes. Some of the previous research shows that gender is a variable that has the potential to be a differentiator in the study of moral development. We try to confirm this suggestion with this study. According to Kohlberg (1971), females are more likely to be in stage 3 at Kohlberg's moral development stage, which is in accordance with interpersonal conformity. Empirical studies by Shaub (1994) and Thoma (1986) show that females have higher levels of individual ethical reasoning than males. Females are less willing to submit to the high demands of life and in giving judgments, they are more influenced by feelings of affection or hostility (Arfaoui et al., 2016). This phenomenon affects their decision and their moral development. Females are more concerned with ethical issues related to legality or justice issues than males. Most studies on gender issues support the hypothesis that females are more sensitive to ethical dilemmas than males. 


\section{Conclusions}

The first purpose of this study is to examine the difference in DIT scores between the students who have taken the ethics subject and who have not taken yet. The second objective is to examine the difference in DIT scores between male and female students. The results show that there is no difference between participants who have taken the ethics subject and who have not taken yet. It strengthens the previous studies that ethics courses or ethics education did not have a significant impact on moral development. Our result about gender confirms that females have a higher DIT score than males.

The study results give some important implications. First, ethics education may be a serious problem since much of the previous research found no significant effect. We state that this study is not about whether ethics education is important or not, but is about the curriculum and supporting systems. Although universities are concerned about imbibing better ethics in accounting students, nothing much can be done because the curriculum does not meet the purpose and there is no support from the faculty members. Future research should consider this issue. Second, practitioners and the accounting body should support universities to develop the ethics program. The gaps between academics and practical environment may result in incompatibility in ethics skills between students and field needs. Future research can examine the role of the professional body in CMD.

Some limitations are also found in this study. A larger sample and more universities may be added to get more robust results. Although we use 17 universities in Indonesia, it may not be enough because the proportion of the sample for each university is small. Also, we just focused on one demographic data that is gender. Other demographic data that has a potential effect on CMD must be explored. Future research may conduct a long-term study to see the moral development phenomena in university.

\section{References}

Abdolmohammadi, M. J., Read, W. J., \& Scarbrough, D. P. (2003). Does selection-socialization help to explain accountants' weak ethical reasoning? Journal of Business Ethics, 42(1), 71-81. https://doi.org/10.1023/A:1021691001119

Alimbudiono, R. S. (2020). Accounting knowledge as a contributing intention on improving public accounting profession. Journal of Asian Finance, Economics and Business, 7(9), 801-809. https://doi.org/10.13106/jafeb.2020.vol7.no9.801

Arfaoui, F., Damak-Ayadi, S., Ghram, R., \& Bouchekoua, A. (2016). Ethics education and accounting students' level of moral development: experimental design in Tunisian audit context. Journal of Business Ethics. https://doi.org/10.1007/ s10551-015-2643-Z
Ariail, D., Abdolmohammadi, M., \& Smith, M. (2012). Ethical predisposition of certified public accountants: A study of gender differences. Research on Professional Responsibility and Ethics in Accounting, 16, 29-56. https://doi.org/10.1108/ S1574-0765(2012)0000016005

Armstrong, M. B. (1987). Moral development and accounting education. Journal of Accounting Education, 5(1), 27-43. https://doi.org/https://doi.org/10.1016/0748-5751(87)90036-4

Aryanti, C., \& Adhariani, D. (2020). Students' perceptions and expectation gap on the skills and knowledge of accounting graduates. Journal of Asian Finance, Economics and Business, 7(9), 649-657. https://doi.org/10.13106/jafeb.2020.vol7.no9.649

Ausubel, D. P. (1962). A subsumption theory of meaningful verbal learning and retention. Journal of General Psychology. 66(April), 213-224.https://doi.org/10.1080/0022 1309.1962.9711837

Dawson, L. M. (1992). Will feminization change the ethics of the sales profession? Journal of Personal Selling \& Sales Management, 12(1), 21-32. https://doi.org/10.1080/08853134 .1992 .10753895

Dellaportas, S., Cooper, B. J., \& Leung, P. (2006). Measuring moral judgement and the implications of cooperative education and rule-based learning. Accounting \& Finance, 46(1), 53-70. https://doi.org/10.1111/j.1467-629X.2006.00161.x

DeTienne, K. B., Ellertson, C. F., Ingerson, M. C., \& Dudley, W. R. (2019). Moral development in business ethics: An examination and critique. Journal of Business Ethics. https:// doi.org/10.1007/s10551-019-04351-0

Doherty, E. G., \& Eagly, A. H. (1989). Sex differences in social behavior: A social-role interpretation. Contemporary Sociology, 51(9), 909-917. https://doi.org/10.2307/2073813

Eagly, A., \& Wood, W. (1991). Explaining sex differences in social behavior: A meta-analytic perspective. Personality and Social Psychology Bulletin, 17, 306-315. https://doi. org/10.1177/0146167291173011

Fakir, A. N. M. A., \& Jusoh, R. (2020). Board gender diversity and corporate sustainability performance: Mediating role of enterprise risk management. Journal of Asian Finance, Economics and Business, 7(6), 351-363. https://doi. org/10.13106/jafeb.2020.vol7.no6.351

Gaa, J., \& Thorne, L. (2004). An introduction to the special issue on professionalism and ethics in accounting education. Issues in Accounting Education, 19(1), 1-6.

Goldman, A., \& Barlev, B. (1974). The auditor-firm conflict of interests: its implications for independence. The Accounting Review, 49(4), 707-718. https://doi.org/10.1007/s10726-0089120-3

Ho, H. L., Dao, M. H., \& Phan, T. C. (2020). Debt finance among Vietnamese enterprises: The influence of managers' gender. Journal of Asian Finance, Economics and Business, 7(9), 229-239. https://doi.org/10.13106/jafeb.2020.vol7.no9.229

Kohlberg, L. (1971). Stages of moral development: Moral Education. San Francisco, CA: Harper \& Row. 
Kohlberg, L. (1973). The claim to moral adequacy of a highest stage of moral judgment. The Journal of Philosophy. 70(18), 630-646. https://doi.org/10.2307/2025030

Kohlberg, L. (1976). Moral stages and moralization: The cognitive-developmental approach. In: T. Lickona (ed.), Moral development and behavior: theory, research and social issues. New York, NY: Holt, Rinehart and Winston. https://doi. org/10.1017/CBO9781107415324.004

Langenderfer, H. Q., \& Rockness, W. J. (1989). Integrating ethics into the accounting curriculum: Issues, problems, and solutions. Issues in Accounting Education, 4, 58-69. https:// doi.org/ 10.1007/BF00872085

Lockwood, A. L. (1978). The effects of values clarification and moral development curricula on school-age subjects: A critical review of recent research. Review of Educational Research, 48(3), 325-364. https://doi.org/10.2307/1169949

McPhail, K., \& Walters, D. (2009). Accounting and business ethics: An introduction. Taylor \& Francis e-Library. London, UK: Routledge. https://doi.org/10.4324/9780203012628

Murphy, H. J., \& Rest, J. R. (1980). Development in judging moral issues. Canadian Journal of Education. https://doi. org/10.2307/1494347

Neidermeyer, P., Tuten, T., \& Neidermeyer, A. (2003). Gender differences in auditors' attitudes towards lowballing: Implications for future practice. Women In Management Review, 18, 406-413. https://doi.org/10.1108/09649420310507497

O'Leary, C. (2012). Semester-specific ethical instruction for auditing students. Managerial Auditing Journal, 27(6), 598-619. https://doi.org/10.1108/02686901211236418

Owhoso, V. (2002). Mitigating gender-specific superior ethical sensitivity when assessing likelihood of fraud risk. Journal of Managerial Issues, 14(3), 360-374.
Ponemon, L. A. (1990). Ethical judgments in accounting: A cognitivedevelopmental perspective. Critical Perspectives on Accounting, 1(2), 191-215. https://doi.org/10.1016/1045-2354(90)02019-1

Rest, J. R. (1986). Moral development: Advances in research and theory. Journal of Business Ethic, 32, 275-283. https://doi. org/10.1016/B978-0-12-385527-5.00001-2

Rogers, V., \& Smith, A. (2001). ethics, moral development, and accountants-in-training. Teaching Business Ethics, 5, 1-20. https://doi.org/10.1023/A:1026534417024

Septiari, D., \& Maruli, M. (2017). Earnings management behaviour: The role of pressure on behaviour performance. Asian Journal of Business and Accounting, 10(2), 137-163. https://ajba. um.edu.my/article/view/9769.

Shaub, M. K. (1994). An analysis of the association of traditional demographic variables with the moral reasoning of auditing students and auditors. Journal of Accounting Education, 12(1), 1-26. https://doi.org/10.1016/0748-5751(94)90016-7

Smith, A., \& Rogers, V. (2000). Ethics-related responses to specific situation vignettes: Evidence of gender-based differences and occupational socialization. Journal of Business Ethics, 28, 73-85. https://doi.org/10.1023/A:1006388923834

Staubus, G. J. (2005). Ethics failures in corporate financial reporting. Journal of Business Ethics, 57, 5-15. https://doi. org/10.1007/s10551-004-3811-8

Thoma, S. J. (1986). Estimating gender differences in the comprehension and preference of moral issues. Developmental Review, 6(2), 165-180. https://doi.org/https://doi.org/10.1016/ 0273-2297(86)90010-9

Thorne, L. (2001). Refocusing ethics education in accounting: An examination of accounting students' tendency to use their cognitive moral capability. Journal of Accounting Education, 19(2), 103-117. https://doi.org/10.1016/S0748-5751(01)00014-8 